\title{
Multidimensional Analysis of S-alleles from Cross-incompatible Groups of California Almond Cultivars
}

\author{
Kristi K. Barckley, Sandra L. Uratsu, Thomas M. Gradziel, and Abhaya M. Dandekar1 \\ Department of Plant Sciences, University of California, Davis, One Shields Avenue, Davis, CA 95616
}

\begin{abstract}
AdDitional INDEX wORDS. self-incompatibility, S-RNase, Prunus dulcis
Abstract. The California almond industry is the largest supplier of almonds [Prunus dulcis (Miller) D.A. Webb] in the United States and throughout the world. Self-incompatibility is a major issue in almond production as it greatly affects nut set. In this study, we determined full-length sequences for alleles $\mathrm{S}^{\mathrm{a}}$ - $\mathrm{S}$, determined the genotypes of 44 California cultivars, and assigned the cultivars to cross-incompatibility groups (CIGs). Newly identified S-alleles led to an increase in the number of CIGs. A pairwise distance tree was constructed using the aligned amino acid sequences showing their similarity. Four pairs of alleles ( $S^{c}$ and $S^{e}, S^{g}$ and $S^{\mathrm{h}}, S^{\mathrm{d}}$ and $S^{j}$, and $S^{b}$ and $S^{\mathrm{f}}$ ) showed high sequence similarity. Because of its simplicity, reproducibility, and ease of analysis, PCR is the preferred method for genotyping S-alleles.
\end{abstract}

According to the Almond Board of California (2004), nearly 470 million $\mathrm{kg}$ of almonds were harvested in California in 2004. One-third was consumed domestically, while 328 million $\mathrm{kg}$ of almonds were exported, making California the number one supplier of almonds worldwide.

One of the major issues surrounding the almond industry is a genetic phenomenon known as self-incompatibility (SI). This naturally occurring process is the reason growers need pollinizers. Without cross-compatible cultivars, almonds would not be able to set their edible seed. SI suppresses inbreeding and promotes out-crossing (de Nettancourt, 1977). Almond, a member of Prunus L., exhibits gametophytic SI (GSI) that operates from a single, multi-alleleic locus (Dicenta and Garcia, 1993; Lewis and Crowe, 1954). In the Solanaceae, the pistil gene product is an S-RNase that consists of five conserved regions (C1-C5) and two hypervariable regions (HVa and $\mathrm{HVb}$ ) (Ioerger et al., 1991). In almond, S-RNases contain five conserved regions, one hypervariable region, and two introns (Ortega et al., 2005; Ushijima et al., 1998). The structural properties of S-RNases have been useful in genotyping almond cultivars (Bošković et al., 1997, 1999, 2003; Channuntapipat et al., 2001, 2003; Ma and Oliveira, 2001; Ortega et al., 2005; Tamura et al., 2000; Ushijima et al., 1998). Although no definitive mechanism for SI has been described, SI has been reviewed in detail by McCubbin and Kao (2000), Silva and Goring (2001), Stone (2002), and Stone and Goring (2001).

The ability to produce a self-compatible and self-fruitful almond cultivar would eliminate the need for growers to incur the expense of pollinizers and pollinator bees. Until that option becomes widely available, we are assisting growers and nurseries to identify potential cross-compatible cultivars prior to planting,

Received for publication 13 Sept. 2005. Accepted for publication 13 May 2006. This manuscript is dedicated to the memory of Dale Kester. We thank the Almond Board of California for their support of this research. We also thank Mihoko Tamura for her contributions, Dan Potter for his help with the construction of the pairwise distance tree, Warren Micke, Fowler Nurseries, Bruce Lampinen, John Edstrom, Steve Wienbaum, Burchell Nursery, Wolley Nursery, Paramount Nursery, Drew Scofield, Tom Ferrari, Mark Freeman, Jim Yaeger, Joe Connell, and many other growers, nurseries, and beekeepers who have supplied almond samples and observations on nut set and pollen compatibilities in commercial orchards.

'To whom reprint requests should be addressed. e-mail: amdandekar@ucdavis. edu; phone: +1 530-752-7784. thus reducing the cost of misplantings. This research is an extension of work by Kester et al. (1994) and Ushijima et al. (1998).

\section{Materials and Methods}

Plant material. Young almond leaves were collected and used to extract DNA from 44 cultivars (Table 1). Styles were collected during the popcorn stage of flower development and used for RNA extraction. The styles were frozen at $-80{ }^{\circ} \mathrm{C}$ until needed. Samples were collected from cultivars at the Univ. of California orchards in Davis and Winters, Calif., and from growers throughout California.

DNA AND RNA ISOLATION. DNA was isolated from $100 \mathrm{mg}$ of young almond leaves using the DNeasy Plant Mini Kit (Qiagen, Valencia, Calif.). Grinding of leaf tissue was accomplished using a TissueLyser (Qiagen). The tissue was weighed and placed in $1.5-\mathrm{mL}$ tubes, frozen with liquid nitrogen and broken up into smaller pieces using a pointed spatula. A 3-mm tungsten carbide bead was placed into each tube along with the AP1 buffer and 3 $\mu \mathrm{L}$ RNase $\mathrm{A}$. The tubes were placed in previously cooled blocks and shaken for $2 \mathrm{~min}$ at a frequency of 30 times/s. Total RNA was extracted from $200 \mathrm{mg}$ of styles from 'Winters', 'Harriot', and 'UCD 25-75' using the RNeasy Plant Mini Kit (Qiagen).

cDNA SYNTHESIS. RNA was converted to cDNA using the Marathon cDNA Amplification Kit (Clontech, Mountain View, Calif.).

Cloning and Sequencing of DNA. Amplification of the S-alleles was accomplished using primers AS 1II ( $5^{\prime}$ TATTTCAATTTGTGCAACAATGG3'), AmyC5R (5'CAAAATACCACTTCATGTAACAAC $\left.3^{\prime}\right)$, Alsc1 (5'CAGACACTTAATCAATTCCAG3') and Alsd2 (5'GTGTATCCTCAGTTGCGAACCA3 $\left.{ }^{\prime}\right)$ as described by Tamura et al. (2000). Polymerase chain reaction (PCR) was used to amplify S-alleles from genomic DNA using the program: $1 \min 94^{\circ} \mathrm{C}, 2 \min 55^{\circ} \mathrm{C}$, and $2 \min 65^{\circ} \mathrm{C}, 20-25$ cycles. The PCR products were cloned into a pCR2.1 TOPO vector (Invitrogen, Carlsbad, Calif.). DNA from positive clones was extracted using the QIAprep Spin Miniprep Kit (Qiagen, Valencia, Calif) and sequenced by Davis Sequencing (Davis, Calif.). Sequence results were analyzed using Sequencher (Gene Codes Corp., Ann Arbor, Mich.) and MacDNAsis programs (Hitachi Software, San Bruno, Calif.). 
Table 1. California almond cultivars placed into cross-incompatibility groups (CIGs) based upon their S-alleles. The cultivars listed within the same row or CIG designation are incompatible pollinizers, but are compatible with cultivars listed in differing CIGs. Bolded cultivars indicate previously genotyped cultivars and the cultivars genotyped in this manuscript are unbolded. Genotypes were based on PCR of intron length polymorphisms. Successful cross-compatibility between CIGs has been confirmed by growers and nurseries throughout California. While the European alleles are not 100\% homologous to the California alleles, the European genotypes listed have either been reported using the same cultivars or based on alignment of all the sequence data are the most similar to the California genotypes listed.

\begin{tabular}{|c|c|c|c|}
\hline $\mathrm{CIG}$ & Genotype & Almond cultivars & $\begin{array}{r}\text { European } \\
\text { genotype }\end{array}$ \\
\hline$\overline{\mathrm{I}}$ & $\mathrm{Sc}^{\mathrm{d}}$ & Nonpareil, Tardy Nonpareil, Grace, West Steyn, UCD F8:7-180, Galaxy & $\mathrm{S}_{7} \mathrm{~S}_{8}$ \\
\hline II & $\mathrm{SaS}^{\mathrm{b}}$ & Mission & $\mathrm{S}_{5} \mathrm{~S}_{1}$ \\
\hline III & $\mathrm{SaSc}$ & Thompson, Sauret no.2, Mono, Wood Colony, Durango, Le Grand, Wassum & $\mathrm{S}_{5} \mathrm{~S}_{7}$ \\
\hline IV & $\mathrm{SbS}$ & Merced, Ne Plus Ultra, Rosetta, Price cluster, Aldrich, Pearl, Jenette, Sano & $\mathrm{S}_{1} \mathrm{~S}_{7}$ \\
\hline $\mathrm{V}$ & $\mathrm{SaS}^{\mathrm{d}}$ & Carmel, Sauret no. 1, Livingston & $\mathrm{S}_{5} \mathrm{~S}_{8}$ \\
\hline VI & $\mathrm{Sb}^{\mathrm{b}} \mathrm{d}$ & $\begin{array}{l}\text { Monterey, Butte, Dottie Won, Plateau, Avalon, UCD D3-25, UCD F8:7-179, } \\
\text { Folsom, Blue Gum }\end{array}$ & $\mathrm{S}_{1} \mathrm{~S}_{8}$ \\
\hline VII & $\mathrm{Sa}^{\mathrm{a}} \mathrm{Si}$ & Arbuckle & $\mathrm{S}_{5} \mathrm{~S}_{?}$ \\
\hline VIII & $\mathrm{S}^{\mathrm{b}} \mathrm{Se}$ & Fritz, Ruby, Peerless & $\mathrm{S}_{1} \mathrm{~S}_{6}$ \\
\hline IX & $\mathrm{SbSh}^{\mathrm{b}}$ & Padre & $\mathrm{S}_{1} \mathrm{~S}_{18}$ \\
\hline $\mathrm{X}$ & $\mathrm{S} b \mathrm{Sj}$ & UCD 13-1 (Winters), UCD 36-52 & $\mathrm{S}_{1} \mathrm{~S}_{14}$ \\
\hline XI & $\mathrm{ScSe}$ & Tokyo & $\mathrm{S}_{7} \mathrm{~S}_{6}$ \\
\hline XII & $\mathrm{ScSg}$ & Milow & $\mathrm{S}_{7} \mathrm{~S}_{13}$ \\
\hline XIII & $\mathrm{ScSj}$ & Jordanolo & $\mathrm{S}_{7} \mathrm{~S}_{14}$ \\
\hline XIV & $\mathrm{Sd} \mathrm{Se}^{2}$ & Kochi, UCD F8:8-160 & $\mathrm{S}_{8} \mathrm{~S}_{6}$ \\
\hline XV & $\mathrm{S} \mathrm{d} \mathrm{Sg}$ & Solano, Sonora, Vesta, Kapareil, UCD F8:7-161 & $\mathrm{S}_{8} \mathrm{~S}_{13}$ \\
\hline XVI & $\mathrm{S}^{\mathrm{d}} \mathrm{S}^{\mathrm{i}}$ & UCD $25-75$ & $\mathrm{~S}_{8} \mathrm{~S}_{?}$ \\
\hline XVII & $\mathrm{SeS}^{\mathrm{j}}$ & Harriot & $\mathrm{S}_{6} \mathrm{~S}_{14}$ \\
\hline XVIII & $\mathrm{Sa}^{\mathrm{a}} \mathrm{Sj}$ & Carrion & $\mathrm{S}_{5} \mathrm{~S}_{14}$ \\
\hline XIX & $S^{d}$ & Jeffries, UCD 3-6, Johlyn & $\mathrm{S}_{8}$ \\
\hline $\mathrm{XX}$ & $\mathrm{S}^{\mathrm{f}}$ & Tuono & $\mathrm{S}_{\mathrm{f}}$ \\
\hline XXI & $\mathrm{S}^{\mathrm{k}}$ & UCD 54P455 (peach) & --- \\
\hline
\end{tabular}

References for alleles include Bošković et al., 1997; Channuntapipat et al., 2001, 2003; Ma and Oliveira et al., 2001.

5'-AND 3'-RACE. RACE was performed on S-alleles, $\mathrm{S}^{\mathrm{a}}$-Si, using the Marathon cDNAAmplification Kit (Clontech). The desired product was purified using Gene Clean (QBiogene, Irvine, Calif.) and cloned. Reverse primers of AS1II and AmyC5R (universal primers) were used for $3^{\prime}$ - and 5'-RACE, respectively. Procedures for cloning, sequencing and analysis were as described above.

INTRON I AMPLIFICATION. Primers flanking intron I (see Table 2 for primer sequences) were designed from sequences obtained from 5'-RACE procedures. Intron I was amplified from DNA of young almond leaves using PCR $\left(1 \min 94^{\circ} \mathrm{C}, 2 \min 55^{\circ} \mathrm{C}\right.$, and 2 min $65^{\circ} \mathrm{C}, 25$ cycles). The PCR product was TOPO cloned and sequenced as described above.

ProteIn COMPARISONS. SRNase sequences were obtained from GenBank. Apple (Malus $\times$ domestica Borkh.) sequences were from accession numbers AY187627, AY039702 and AY201748. European almond $S$ alleles were represented by accession numbers AAF73756, AAG09286, AAF82613, AAG09287, AAK58577, AAK58579, AAK58580 corresponding to sequences from Ma and Oliviera $(2001,2002)$ for $\mathrm{S}_{1}$ and $\mathrm{Se}-\mathrm{S} \mathrm{j}$, respectively. California almond $\mathrm{S}$ alleles were from accession numbers (BAA95317, AAD51787, AAD51788, andAAD51789) corresponding to $S^{\mathrm{a}-S \mathrm{~S}}$, respectively (Tamura et al., 1999; Ushijima et al., 1998). For a list of accession numbers corresponding to sequences determined in this work refer to Table 3.

Four S-alleles, $\mathrm{Sg}_{-}-\mathrm{S}$, isolated from European cultivars were compared with California $\mathrm{S}$-alleles $\mathrm{S}^{\mathrm{a}-\mathrm{Sj}}$ and percent homolog calculated. Amino acid sequences were aligned using Clustal X (Thompson et al., 1997). Three amino acid sequences from apple were aligned with the almond S-alleles. The pairwise distance
Table 2. Oligonucleotide primers used for 5'-RACE amplification of full length cDNA encoding S-RNase alleles of the almond cultivars, 'Mission', 'Nonpareil', 'Peerless', 'Sonora', 'Sonoma', 'UCD 25-75', 'Winters', and 'Tuono'.

\begin{tabular}{|c|c|}
\hline Alleles & Forward primers \\
\hline$\overline{\mathrm{S}^{\mathrm{a}}}$ & 5'GTCCTCTTCTTGTGTTTCACTA3' \\
\hline $\mathrm{S}^{\mathrm{b}} / \mathrm{S}^{\mathrm{f}}$ & 5'CCTCTCCCATTCTGTAGTTTC3' \\
\hline $\mathrm{S}^{\mathrm{c}}$ & 5'GTTGAAATCGTCACTCGCTTTCC3' \\
\hline $\mathrm{S}^{\mathrm{d}}$ & 5'GTGTTTCATTATGAGCAC3' \\
\hline $\mathrm{Se}$ & 5'CTCTCATTCTGTTGTATTTCTTGTTGC3' \\
\hline $\mathrm{Sg}$ & 5'GTATTCTCCTAGTATGGGGATGTTGAAATCGTC3' \\
\hline $\mathrm{S}^{\mathrm{h}}$ & 5'CTCATTCTGTTGTATTTCTTGTTGC3' \\
\hline $\mathrm{S}^{\mathrm{i}}$ & 5'GCTTTCTTCATGTGTTTCATTATGTGC3' \\
\hline $\mathrm{S}^{\mathrm{j}}$ & 5'GCAGGTGCGATGTTGAAATCGTCACTCGGTTTCC3 \\
\hline Name & Reverse primer \\
\hline $\mathrm{RC} 1$ & 5'CCATTGTTGCACAAATTGAAAATA3' \\
\hline
\end{tabular}

tree, based on the aligned amino acid sequences, using the neighbor joining method was constructed using PAUP* version 4.0 (Swofford, 2002). Bootstrap analysis of 1000 replicates was also completed. Additionally a pairwise distance tree was constructed with almond S-alleles determined by Ma and Oliviera (2002).

\section{Results}

Genetic analysis of S-alleles. Six S-alleles $\left(\mathrm{Se}_{-} \mathrm{S} \mathrm{j}\right)$ were amplified by PCR, cloned, and sequenced. In addition, RACE was performed for all S-alleles $\left(\mathrm{S}^{\mathrm{a}}-\mathrm{S}\right.$ ) $)$ to determine sequences at the $5^{\prime}$ and $3^{\prime}$ ends. Large differences in the size of the two introns 
Table 3. GenBank accession numbers and corresponding DNA sequences encoding individual S-RNase alleles from different almond cultivars.

\begin{tabular}{|c|c|}
\hline Accession no. & Description \\
\hline$\overline{\text { DQ150569 }}$ & Sa-RNase, Mission, gDNA \\
\hline DQ133943 & $\mathrm{S}^{\mathrm{b}}-\mathrm{RNase}$, intron I, gDNA \\
\hline DQ133944 & $\mathrm{S}^{\mathrm{c}-\mathrm{RN}}$ ase, intron I, gDNA \\
\hline DQ133945 & $\mathrm{S}^{\mathrm{d}}-\mathrm{RNase}$, intron I, gDNA \\
\hline DQ156216 & Se-RNase, Peerless, gDNA \\
\hline DQ157873 & Se-RNase, Peerless, mRNA \\
\hline DQ156217 & Sf-RNase, Tuono, gDNA \\
\hline DQ157874 & Sf-RNase, Tuono, mRNA \\
\hline DQ156218 & Sg-RNase, Sonora, gDNA \\
\hline DQ157875 & $\mathrm{S}^{\mathrm{g}}-\mathrm{RN}$ ase, Sonora, mRNA \\
\hline DQ156219 & 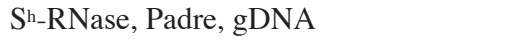 \\
\hline DQ157876 & 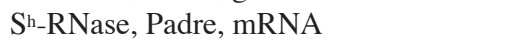 \\
\hline DQ059314 & Si-RNase, UCD 25-75, Arbuckle, mRNA \\
\hline DQ058401 & Si-RNase, Arbuckle, gDNA \\
\hline DQ058402 & Si-RNase, UCD 25-75, gDNA \\
\hline DQ059313 & Si-RNase, Winters, Harriet, mRNA \\
\hline DQ058403 & Si-RNase, Winters, gDNA \\
\hline DQ058404 & $\mathrm{Si}^{\mathrm{j}}$-RNase, Winters, gDNA \\
\hline
\end{tabular}

were observed (Table 4). These differences in intron size allow characterization of S- alleles by PCR.

A comparison of amino acid sequences was performed (Fig. 1) to determine exon differences. It should be noted that $S^{k}$ was not included in this analysis because it is derived from peach and is not a true almond allele. All the alleles maintained the overall structure of five conserved regions, two introns, and a hypervariable region, but showed individual differences, especially within the hypervariable region. More single amino acid changes seemed to occur in conserved region $\mathrm{C} 4$ than regions $\mathrm{C} 1,2,3$, or 5 . Although there are still some unknown sequences at the $5^{\prime}$ and $3^{\prime}$ end of the alleles, the most important regions of the sequences are evident from the analysis.

Cross-InCompatible groups (CIGs). The ability to identify S-alleles using PCR allows rapid genotyping of cultivars and their assignment to a CIG (Table 1). The European designations of the alleles are shown. Cultivars within a CIG are cross-incompatible and thus not suitable for use as pollinizers. Thus, Table 1 groups the cultivars in such a way as to help determine potential pollinizers based on the S-alleles. Any new almond cultivars can easily be tested and added to the chart.

Pairwise distance tree. Using amino acid alignment, a pairwise distance tree was constructed (Fig. 2). The tree shows that the apple sequences are genetically different from the almond $\mathrm{S}$-alleles. Analysis of the almond $\mathrm{S}$-alleles indicates that the $\mathrm{S}^{\mathrm{a}}$ allele was perhaps a progenitor S-allele from which all others were derived, as it is an outlier in Fig. 2. It is interesting to note that the $\mathrm{Si}$ allele is the only one that does not seem to be closely related to another S-allele. According to the bootstrap analysis, $\mathrm{S}^{\mathrm{b}}$ of 'Mission' and $\mathrm{S}^{\mathrm{f}}$ of 'Tuono' are the only pair that is highly similar. The other pairings did not derive very high bootstrap percentages and therefore may not be as strongly similar as the tree suggests.

\section{Discussion}

Genetic analysis of S-RNaSes. We successfully identified $10 \mathrm{~S}$-alleles $\left(\mathrm{S}^{\mathrm{a}-\mathrm{S}} \mathrm{j}\right)$ in all known California almond cultivars. As shown by Tamura et al. (2000), a simple PCR confirms each
Table 4. List of intron length polymorphisms for S-alleles in almond. Intron lengths were determined by PCR, cloning and sequencing. Specific primers designed from $5^{\prime}$-RACE sequences were used to amplify the intron I region. Universal primers AS1II and Amy C54 (Ushijima et al., 1998) were used for amplification of intron II. Intron II lengths for $\mathrm{S}^{\mathrm{a}}-\mathrm{S}^{\mathrm{d}}$ were previously reported by Ushijima et al. (1998).

\begin{tabular}{lcrl}
\hline & Intron I (bp) & Intron II (bp) & Cultivar \\
\hline $\mathrm{S}^{\mathrm{a}}$ & 807 & 84 & Mission \\
$\mathrm{S}^{\mathrm{b}}$ & 797 & 556 & Mission \\
$\mathrm{S}^{\mathrm{c}}$ & 275 & 1526 & Nonpareil \\
$\mathrm{S}^{\mathrm{d}}$ & 327 & $>3500$ & Nonpareil \\
$\mathrm{S}^{\mathrm{e}}$ & 276 & 328 & Peerless \\
$\mathrm{S}^{\mathrm{f}}$ & 801 & 561 & Tuono \\
$\mathrm{S}^{\mathrm{g}}$ & 302 & 832 & Sonora \\
$\mathrm{S}^{\mathrm{h}}$ & 215 & 129 & Padre \\
$\mathrm{S}^{\mathrm{i}}$ & 317 & 710 & UCD 25-75 \\
$\mathrm{S}^{\mathrm{j}}$ & $1075 / 806^{\mathrm{z}}$ & 783 & Winters \\
\hline
\end{tabular}

zIntron size has not been definitively determined.

allele based on intron size differences (Table 4). Each allele has two introns that vary in length, allowing for easy detection and confirmation. Additionally, all S-alleles have the same structural sequence motifs identified for the original four S-alleles $\left(\mathrm{S}^{\mathrm{a}}, \mathrm{S}^{\mathrm{b}}\right.$, $\mathrm{S}^{\mathrm{c}}, \mathrm{S}^{\mathrm{d}}$ ) (Tamura et al., 2000; Ushijima et al., 1998). According to Matton et al.(1997), the HV region is required for allelic specificity and for the pollen rejection mechanism. The aligned amino acid sequences show the $\mathrm{HV}$ region, which is interrupted by intron II, as being highly variable among S-alleles. Therefore, amino acid changes within conserved regions should not have a negative effect on the ability to recognize "self" pollen. Sequences at the 5' end have been analyzed for almost all of the S-alleles, resulting in the identification of the signal peptide, an additional intron (intron I), and the start of the mature protein. The structure as identified by the amino acid comparisons remains similar among the 10 analyzed S-alleles (Fig 1). The $\mathrm{S}^{\mathrm{f}}$ allele cloned in this study is derived from 'Tuono' and has an amino acid sequence identical to the $\mathrm{S}^{\mathrm{b}}$ allele. While our data show that the exons are the same, the introns differ in size (Table 4), indicating that $\mathrm{S}^{\mathrm{f}}$ differs from $\mathrm{S}^{\mathrm{b}}$. However, if the HV region is responsible for allele specificity, then $\mathrm{S}^{\mathrm{f}}$ should be recognized as $\mathrm{S}^{\mathrm{b}}$ as the HV regions are the same. The presence of only one allele, or one self-compatible allele, however, does indicate self-compatibility. In a self-compatible system, pollen is not recognized as "self," and therefore pollen tube growth is not terminated. The cultivar Tuono expresses the $\mathrm{Sf}_{\mathrm{f}}$ allele, a self-compatible allele (Ma and Oliveira, 2001), which has previously been shown to have the genotype $\mathrm{S}_{1} \mathrm{~S}^{\mathrm{f}}$ (Bošković et al., 1997; Sanchez-Perez et al., 2004). However, according to our data, 'Tuono' does not express an $\mathrm{S}^{1}$ allele.

Historically, the European S-alleles are designated with numbers, while the California S-alleles are designated with letters. When the European alleles listed in GenBank were compared with the lettered California alleles, the exon sequences showed almost complete homology. The intron I size of European almond S-alleles was determined by Ortega et al. (2005). When compared with California S-alleles, the intron I lengths were found to be significantly different. Intron II lengths also differed (Channuntapipat et al., 2001; Tamura et al., 2000). Additionally, Ma and Oliveira (2002) identified $\mathrm{Sg}, \mathrm{S}^{\mathrm{h}}, \mathrm{S}^{\mathrm{i}}, \mathrm{Sj}$, and $\mathrm{S}^{\mathrm{k}}$ alleles in European almond cultivars. When the sequences were compared with the sequences from California almonds (data not shown), the majority of homology occurred within the conserved regions. The $\mathrm{S}^{\mathrm{j}}$ allele had the least amount of homology (67\%) between the European and California almonds, while the $\mathrm{S}^{\mathrm{i}}$ allele had the most 


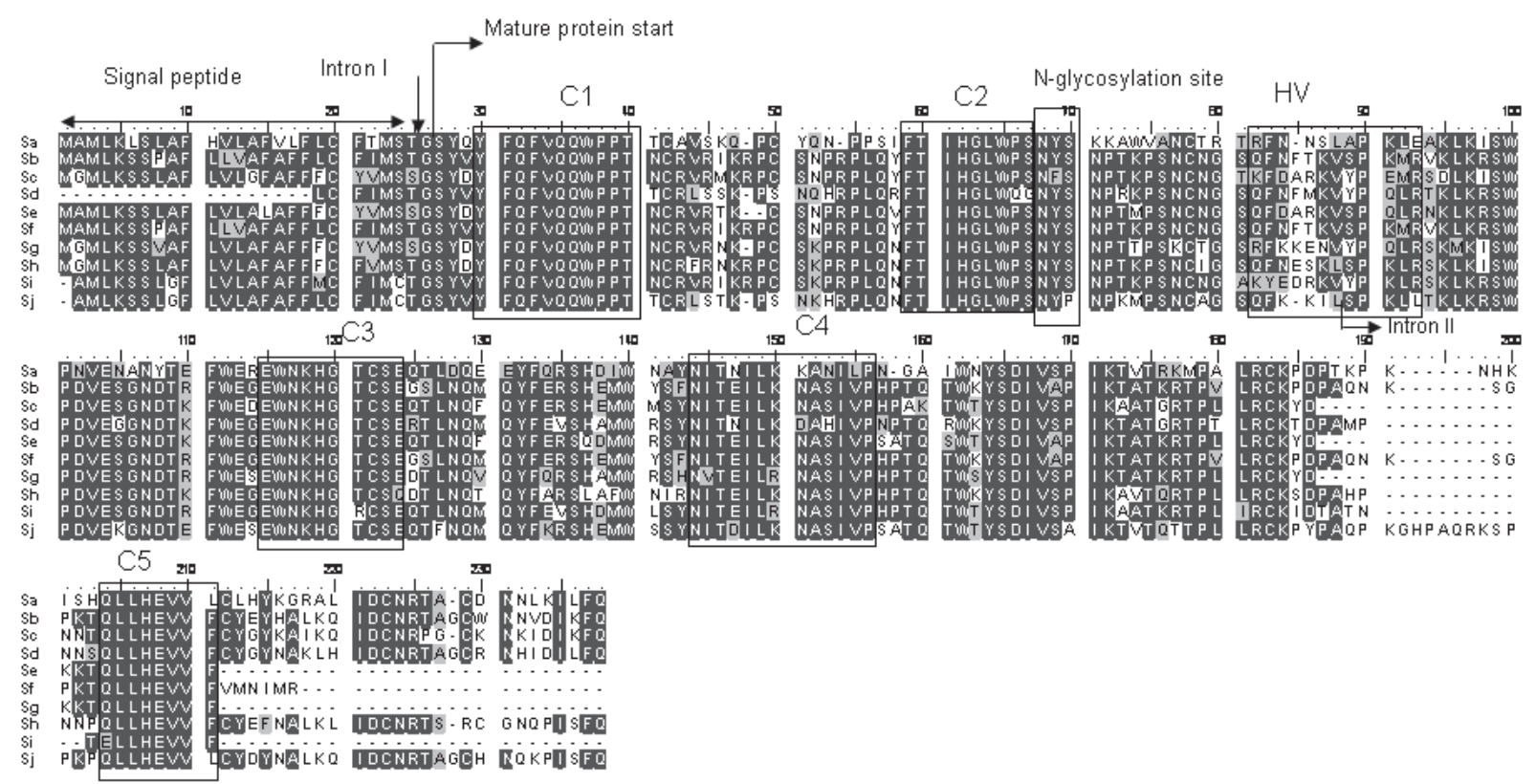

Fig. 1. A multiple alignment of the S-RNase protein sequences obtained from different California almond cultivars. The S-RNase alleles are listed alphabetically in the left hand column. The aligned sequences were obtained from the following almond cultivars 'Mission' ( $\mathrm{S}^{\mathrm{a}}$ and $\left.\mathrm{S}^{\mathrm{b}}\right)$, 'Nonpareil' ( $\mathrm{S}^{\mathrm{c}}$ and $\mathrm{S}^{\mathrm{d}}$ ), 'Peerless' $\left(\mathrm{S}^{\mathrm{e}}\right)$, 'Tuono' $\left(\mathrm{S}^{\mathrm{f}}\right)$, 'Sonora' $(\mathrm{S})$ ), 'Padre' $\left(\mathrm{S}^{\mathrm{h}}\right)$, 'UCD 25-75' $\left(\mathrm{S}^{\mathrm{i}}\right)$, 'Winters' $\left(\mathrm{S}^{\mathrm{j}}\right)$. The amino acid sequences were aligned using the program Bioedit $(\mathrm{Ibis}$ Therapeutics, Carlsbad, Calif.), that uses Clustal W to align the sequences. Homology between alleles is shown by shading. The conserved areas are boxed and labeled C1-C5 and the hypervariable region is boxed and labeled HV. The signal peptide region occurs prior to the start of the mature protein and was determined based on 5'-RACE sequence identification. Intron I occurs just upstream of the mature protein and intron II intersects the HV region. The intron I sequences were determined from a specific PCR of the 5' region and the intron II sequences were determined using universal primers (Ushijima et al., 1998). The exact positions of the introns and the start of the mature protein were based on DNA sequence, start codon locations, and N-terminal sequence as described by Tao et al. (1997).

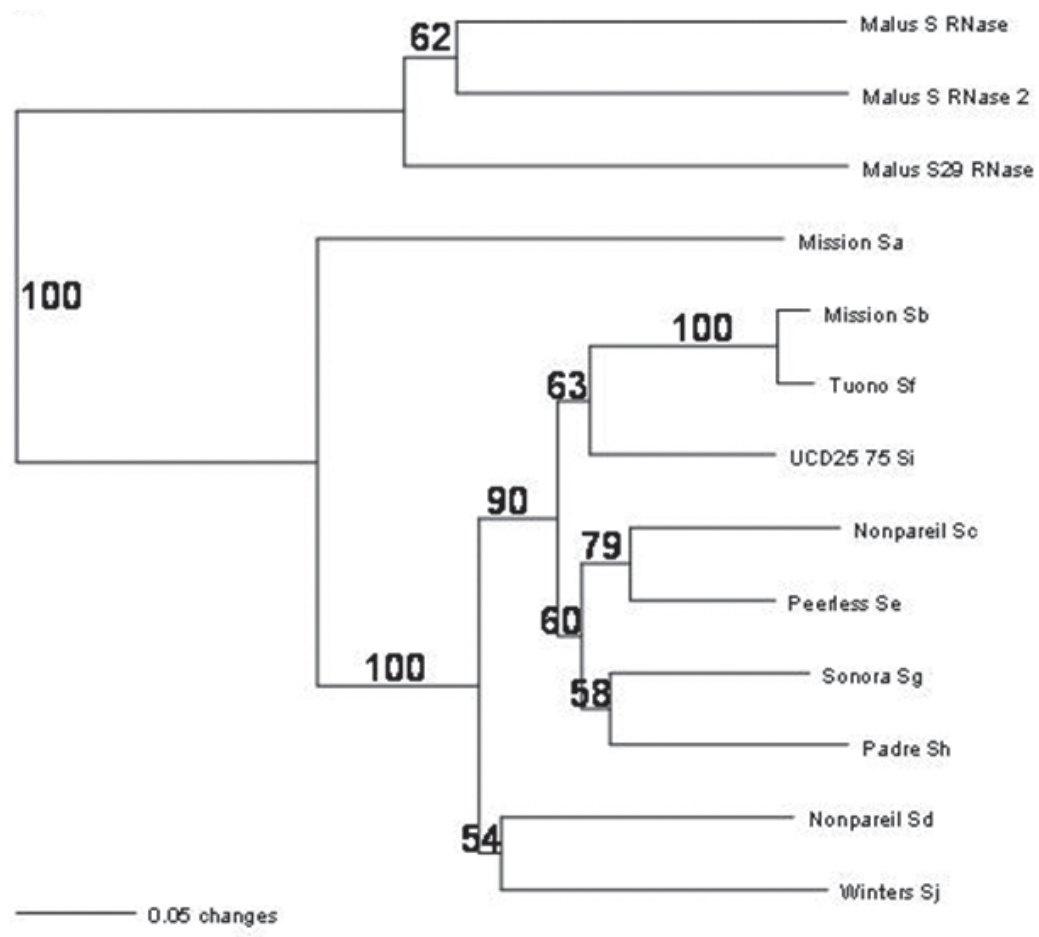

Fig. 2. Construction of a pairwise distance tree of California almond S-RNases based on a amino acid alignment with Clustal X. Almond cultivars from which the sequences were determined are the same as those previously mentioned in Fig. 1. The tree and bootstrap analysis were constructed using PAUP* version 4.0. Sequences from Malus $\times$ domestica served as an out-group. Four pairs $\left(\mathrm{Sc}^{\mathrm{c}}\right.$ and $\mathrm{Se}, \mathrm{Ss}$ and $\mathrm{Sh}$, $\mathrm{S}^{\mathrm{d}}$ and $\mathrm{Si}$, and $\mathrm{S}^{\mathrm{b}}$ and $\mathrm{S}^{\mathrm{f}}$ ) segregated out, indicating high homology between them relative to the other $\mathrm{S}$-alleles. $\mathrm{S}^{\mathrm{i}}$ was the only $\mathrm{S}$-allele that was not closely linked with any other S-allele, while the $S^{a}$ allele was perhaps a progenitor S-allele from which all others were derived, as it is an outlier. homology (81\%). Additionally, the $\mathrm{S}^{\mathrm{f}}$ allele, cloned from 'Tuono' by Ma and Oliveira (2001) differs in sequence from the $\mathrm{S}_{\mathrm{f}}$ allele isolated in this study using the same cultivar. Therefore, it can be said that the alleles found in European and Californian cultivars are similar but not identical.

Cross-InCompatible groups (CIGs). This study added 15 CIGs to the six previously identified by Kester et al. (1994). The original CIGs were determined through cross-pollinations and zymograms (Kester et al., 1994). The genotypes of 'Ruby', 'Aldrich', and 'Pearl' (cultivars also analyzed in this study) were previously determined using zymograms (Bošković et al., 1997, 1999, 2003; Channuntapipat et al., 2001). Due to the difference in methods, discrepancies have arisen between previous genotype designations (Bošković et al., 1997, 1999, 2003; Channuntapipat et al., 2001; Kester et al., 1994) and the genotypes/CIGs assigned in this research. Previously the genotype designations as determined by Bošković et al. (1997, 1999, 2003), Channuntapipat et al. (2001), and Kester et al. (1994), were 'Ruby' $\left(\mathrm{S}_{6}{ }^{\circ} \mathrm{S}_{16}\right)$, 'Aldrich' $\left(\mathrm{S}_{7}{ }^{\mathrm{C}} \mathrm{S}_{17}\right)$, and 'Pearl' $\left(\mathrm{S}_{7}{ }^{\mathrm{c}} \mathrm{S}_{16}\right)$. The CIGs designated in this study ['Ruby' $\left(\mathrm{S}^{\mathrm{b}} \mathrm{S} \mathrm{e}\right)$, 'Aldrich' $\left(\mathrm{S}^{\mathrm{b}} \mathrm{S}^{\mathrm{c}}\right)$, and 'Pearl' $\left.\left(\mathrm{S}^{\mathrm{b}} \mathrm{S}^{\mathrm{c}}\right)\right]$ were a product of a multidimensional analysis using PCR to genotype the almond cultivars, followed by sequencing of the alleles (cDNAand gDNA) for specific confirmation. Our CIGs are consistent with the observations at the Univ. of California almond breeding program (directed by T. Gradziel) and several individuals in the California almond industry. Intron I amplification was used for additional confirmation. The PCR and 
sequencing method gave clear reproducible results. These methods have been used to determine S-alleles in such systems as sweet cherry (Prunus avium L.), sour cherry (Prunus cerasus L.), and apricot (Prunus armeniaca L.) (Hauck et al., 2002; Sonneveld et al., 2001; Tao et al., 2002; Wunsch and Hormaza, 2004). Because of its simplicity, reproducibility, and ease of analysis, PCR is the preferred method for genotyping S-alleles.

Pairwise distance Tree. Ushijima et al. (1998) compared SRNases from different Rosaceae species in terms of their evolution. Our pairwise distance tree breaks down the larger picture by examining the relationships between individual S-alleles. Four pairs of alleles ( $\mathrm{S}^{\mathrm{c}}$ and $\mathrm{Se}^{\mathrm{e}}, \mathrm{S}^{\mathrm{g}}$ and $\mathrm{S}^{\mathrm{h}}, \mathrm{S}^{\mathrm{d}}$ and $\mathrm{Sj}$, and $\mathrm{S}^{\mathrm{b}}$ and $\mathrm{S}^{\mathrm{f}}$ ) have very few nucleotide substitutions, signifying that they are closely related. Ma and Oliveira (2002) formulated a phylogenetic tree showing the evolutionary relationships between $\mathrm{S}$-alleles in various Rosaceae species. The relationships between $\mathrm{S}$-alleles as determined by Ma and Oliveira (2002) do not correlate with our results. Additionally, Ma and Oliveira (2002) added additional sequences from other species. When the almond $\mathrm{S}$-allele sequences were aligned and put into a pairwise distance tree using the same method for constructing our tree, a different output resulted (data not shown). The tree differed from the published tree, which was expected, but it also differed from our pairwise distance tree. The differences between the European S-allele tree we constructed and the tree in this manuscript are partly due to the differences in sequences used. The pairwise distance tree constructed from our amino acid alignment was based on full-length sequences whereas the sequences listed by Ma and Oliveira (2002) are only partial sequences and are not $100 \%$ homologous with the sequences aligned in this manuscript. Due to these variances, different clustering of alleles was expected.

\section{Conclusion}

This research expanded the number of known S-alleles in California almond cultivars and also increased the number of CIGs. PCR-based genotyping of almond cultivars remains the preferred method to determine their cross-compatibility. Until future research can expand our knowledge of the self-incompatibility system, genotyping of almond cultivars is the ideal way to determine the compatibility of cultivars.

\section{Literature Cited}

Almond Board of California. 2004. Almond almanac. Almond Board of California, Modesto, Calif.

Bošković, R., K.R. Tobutt, I. Batlle, and H. Duval. 1997. Correlation of ribonuclease zymograms and incompatibility of genotypes in almond. Euphytica 97:167-176.

Bošković, R., K.R. Tobutt, H. Duval, I. Batlle, F. Dicenta, andF.J. Vargas. 1999. A stylar ribonuclease assay to detect self-compatible seedlings in almond progenies. Theor. Appl. Genet. 99:800-810.

Bošković, R., K.R. Tobutt, I. Batlle, H. Duval, P. Martinez-Gomez, and T.M. Gradziel. 2003. Stylar ribonucleases in almond: correlation with and prediction of incompatibility genotypes. Plant Breeding 122:70-76.

Channuntapipat, C., M. Sedgley, and G. Collins. 2001. Sequences of cDNAs and genomic DNAs encoding the S1, S7, S8, and Sf alleles from almond, Prunus dulcis. Theor. Appl. Genet. 103:1115-1122.

Channuntapipat, C., M. Wirthensohn, S.A. Ramesh, I. Batlle, P. Arus, M. Sedgley, and G. Collins. 2003. Identification of incompatibility genotypes in almond (Prunus dulcis Mill.) using specific primers based on the introns of the S-alleles. Plant Breeding 122:164-168.

de Nettancourt, D. 1977. Incompatibility and incongruity in wild and cultivated plants. Springer-Verlag, New York.
Dicenta, F. and J.E. Garcia. 1993. Inheritance of self-compatibility in almond. Heredity 70:313-317.

Hauck, N., H. Yamane, R. Tao, and A.F. Iezzoni. 2002. Self-compatibility and incompatibility in tetraploid sour cherry (Prunus cerasus L.). Sexual Plant Reproduction 15:39-46.

Ioerger, T.R., J.R. Gohlke, B. Xu, and T.H. Kao. 1991. Primary structural features of the self-incompatibility protein in Solanaceae. Sexual Plant Reproduction 4:81-87.

Kester, D.E., T.M. Gradziel, and W.C. Micke. 1994. Identifying pollen incompatibility groups in California almond cultivars. J. Amer. Soc. Hort. Sci. 119:106-109.

Lewis, D. and K. Crowe. 1954. The induction of self-fertility in tree fruits. J. Hort. Sci. 29:220-225.

Ma, R.-C. and M.M. Oliveira. 2001. Molecular cloning of the self-incompatibility genes S1 and S3 from almond (Prunus dulcis cv. Ferragnes). Sexual Plant Reproduction 14:163-167.

Ma, R.-C. and M.M. Oliveira. 2002. Evolutionary analysis of S-RNase genes from Rosaceae species. Mol. Genet. Genomics 267:71-78.

Matton, D.P., O. Maes, G. Laublin, Q. Xike, C. Bertrand, D. Morse, and M. Cappadocia. 1997. Hypervariable domains of self-incompatibility RNases mediate allele-specific pollen recognition. Plant Cell 9:1757-1766.

McCubbin, A.G. and T.H. Kao. 2000. Molecular recognition and response in pollen and pistil interactions. Annu. Rev. Cell. Dev. Biol. 16:333-364.

Ortega, E., B.G. Sutherland, F. Dicenta, R. Bošković, and K.R. Tobutt. 2005. Determination of incompatibility genotypes in almond using first and second intron consensus primers: Detection of new $\mathrm{S}$ alleles and correction of reported S genotypes. Plant Breeding 124:188-196.

Sanchez-Perez, R.,F. Dicenta, andP. Martinez-Gomez. 2004. Identification of S-alleles in almond using multiplex PCR. Euphytica 138:263-269.

Silva, N.F. and D.R. Goring. 2001. Mechanisms of self-incompatibility in flowering plants. Cell. Mol. Life Sci. 58:1988-2007.

Sonneveld, T., T.P. Robbins, R. Bošković, and K.R. Tobutt. 2001. Cloning of six cherry self-incompatibility alleles and development of allelespecific PCR detection. Theor. Appl. Genet. 102:1046-1055.

Stone, J.L. 2002. Molecular mechanisms underlying the breakdown of gametophytic self-incompatibility. Qrtly. Rev. Biol. 77:17-32.

Stone, S.L. and D.R. Goring. 2001. The molecular biology of self-incompatibility systems in flowering plants. Plant Cell Tissue Organ Cult. 67:93-114.

Swofford, D.L. 2002. PAUP*: Phyologenetic analysis using parsimony (*and other methods). Version 4. Sinauer Associates, Sunderland, Mass.

Tamura, M., T.M. Gradziel, and A.M. Dandekar. 1999. Cloning of genomic DNA sequences encoding almond (Prunus dulcis) S-RNase genes. Plant Physiol. 120:1206.

Tamura, M., K. Ushijima, H. Sassa, H. Hirano, R. Tao, T.M. Gradziel, and A.M. Dandekar. 2000. Identification of self-incomaptibility genotypes of almond by allele-specific PCR analysis. Theor. Appl. Genet. 101:344-349.

Tao, R., H. Yamane, H. Sassa, H. Mori, T.M. Gradziel, and A.M. Dandekar. 1997. Identification of stylar RNase associated with gametophytic self-incompatibility in almond (Prunus dulcis). Plant Cell Physiol. 38:304-311.

Tao, R., T. Habu, H. Yamane, and A. Sugiura. 2002. Characterization and cDNAcloning forSf-RNase, a molecular markerfor self-compatibility, in japanese apricot (Prunus mume). J. Jpn. Soc. Hort. Sci. 71:595-600.

Thompson, J.D., T.J. Gibson, F. Plewniak, F. Jeanmougin, and D.G. Higgins. 1997. The ClustalX windows interface: flexible strategies for multiple sequence alignment aided by quality analysis tools. Nucleic Acids Res. 25:4876-4882.

Ushijima, K., H. Sassa, R. Tao,H. Yamane,A.M. Dandekar,T.M. Gradziel, and H. Hirano. 1998. Cloning and characterization of cDNAs encoding S-RNases from almond (Prunus dulcis): Primary structural features and sequence diversity of the S-RNases in Rosaceae. Mol. Gen. Genet. 260:261-268.

Wunsch, A. and J.I. Hormaza. 2004. S-allele identification by PCR analysis in sweet cherry cultivars. Plant Breeding 123:327-331. 